\title{
A Case of Idiopathic-Bilateral Chylothorax
}

\section{Idiopatik Bilateral Şilotoraks Olgusu}

İbrahim Güven Çoşğun', Bayram Metin²

\begin{abstract}
Chylothorax is the collection of lymphatic fluid in the pleural space. Lymphatic fluid in the pleural space may cause metabolic and immunologic disorders. Trauma to the thoracic duct and malignant disease (non-Hodgkin's lymphoma) are the common mechanisms of chylothorax. Other rare causes are lymphangiomyomatosis, tuberculosis, venous thrombosis, congenital lymphatic malformations, nephrotic syndrome, hypothyroidism, cirrhosis and idiopathic chylothorax. A 56-year-old woman presented with dyspnea, reduced appetite and weight loss. A chest x-ray showed left homogenoeus density with a concave interface toward the lung and blunting of right costophrenic angle. Thoracentesis was performed. Milky off-white fluid was aspirated. Analysis of the fluid confirmed the diagnosis of chylothorax. Etiology was not determined. Chylothorax was regressed with conservative treatment. We present a case of rare bilateral-idiopathic chylothorax with regression following conservative therapy.
\end{abstract}

Key words: Chylothorax, bilateral, idiopathic.

\section{Özet}

Şilotoraks plevral boşlukta lenfatik sıvının birikmesiyle oluşan nadir bir klinik tablodur. Lenfatik sıvı birikimi ciddi metabolik ve immünolojik bozukluklara yol açabilir. Şilotoraks çoğunlukla toraks travması ve malign obstrüksiyon (Non-Hodgkin lenfoma) sonucu ortaya çıkar. Daha nadir sebepleri lenfanjiyomiyomatosiz, tüberküloz, venöz tromboz, konjenital lenfatik malformasyon, nefrotik sendrom, hipotroidizm, siroz ve idiopatik şilotorakstır. Elli altı yaşından kadın hasta nefes darlığı, kilo kaybı ve iştah azalması şikâyeti başvurdu. Akciğer grafisinde sol hemitoraksta homojen dansite artışı ve sağ kostovertebral açıda kapanma izlendi. Torasentezde beyaz sütümsü renkli plevral mayi aspire edildi. Plevral mayi biyokimyasal analizi ile şilotoraks tanısı doğrulandı. Şilotoraks nedenleri araştırıldı, etiyolojik patoloji saptanamadı. Konservatif tedavi ile şilotoraksta gerileme izlendi. Bu yazıda, konservatif tedavi ile gerileyen idiyopatik ve bilateral şilotoraks olgumuzu sunduk.

Anahtar Sözcükler: Şilotoraks, bilateral, idiopatik.
'Clinic of Chest Disease, Afyonkarahisar State Hospital, Afyon-

karahisar, Turkey

${ }^{2}$ Department of Thoracic Surgery, Bozok University Faculty of Medicine, Yozgat, Turkey
'Afyonkarahisar Devlet Hastanesi, Göğüs Hastalıkları Kliniği, Afyonkarahisar

${ }^{2}$ Bozok Üniversitesi Tıp Fakültesi, Göğüs Cerrahisi Anabilim Dalı, Yozgat

Submitted (Başvuru tarihi): 22.02.2015 Accepted (Kabul tarihi): 15.06.2015

Correspondence (iletişim): İbrahim Güven Coşğun, Clinic of Chest Disease, Afyonkarahisar State Hospital, Afyonkarahisar, Turkey

e-mail:dr_guven@hotmail.com 
Chylothorax is the leakage of chyle into the pleural space (1). Trauma to the thoracic duct and malignant disease (non-Hodgkin's lymphoma) are the common mechanisms of chylothorax. Other rare causes are lymphangiomyomatosis, tuberculosis, venous thrombosis, congenital lymphatic malformations, nephrotic syndrome, hypothyroidism, cirrhosis and idiopathic chylothorax. Chylothorax is suspected when milky white fluid is obtained during thoracentesis (2). Conservative treatment involves replacing lost nutrients and reducing the flow of chyle through the thoracic duct, allowing the duct to heal. This is achieved by eliminating the intake of dietary fat and supplementing nutrition with oral mediumchain triglycerides, or by total parenteral nutrition (3). The insertion of a chest drain may also be required to remove the pleural fluid and allow re-expansion of the lung. Surgical treatment is indicated when conservative treatment not sufficient.

\section{CASE}

A 56-year-old woman presented with dyspnea, reduced appetite and weight loss. She had no fever, chest pain, cough, joint pain, night sweats, or history of trauma. Her past medical history included a diagnosis of cervical carcinoma treated with chemotherapy and radiotherapy one year previously. The patient underwent colostomy due to a rectovaginal fistula that developed following radiotherapy. In addition, the patient was receiving drug treatment for psychiatric disorders. Physical examination revealed absent breath sounds in the left lower zone. A chest $x$-ray showed left homogenoeus density with a concave interface towards the lung and blunting of the right costophrenic angle (Figure 1). Thoracentesis was performed. Milky off-white fluid was aspirated (Figure 2). It had a protein level of $4.0 \mathrm{~g} / \mathrm{dl}$, albumin: $2.4 \mathrm{~g} / \mathrm{dl}$ a lactate dehydrogenase (LDH) level of $152 \mathrm{IU} / \mathrm{L}$, a glucose level of $256 \mathrm{mg} / \mathrm{dl}$ and a normal $\mathrm{pH}$ level. In the serum sample, the total protein level was $7.1 \mathrm{~g} / \mathrm{dl}$, albumin: 2.4 g/dl, LDH: $284 \mathrm{IU} / \mathrm{L}$. Cholesterol and triglyceride levels were measured in the pleural fluid. Analysis of the fluid reported a triglyceride content of $1689 \mathrm{mg} / \mathrm{dL}$ and cholesterol of $251 \mathrm{mg} / \mathrm{dL}$, which confirmed the diagnosis of chylothorax.

Computed tomography of the thorax (CT) showed bilateal pleural effusion to be more prominent in the left and with passive atelectasis (Figure 3). Conservative treatment was started with a fat-free diet and total parenteral nutrition. Therapeutic thoracentesis was performed and 1 liter of pleural fluid was drained. Chylous fluid was drained from the left chest tube and conservative treatment was continved. Lymphoscintigraphy was conducted to demonstrate the site of the leakage, blockage, and malformations of the thoracic duct. There was no leakage or blockage. Abdomen CT did not show ascites or peritoneal fibrosis. Liver function tests of the biochemical analysis were normal and we did not find liver cirrhosis. Serum free triiodothyronine (T3), free thyroxine (T4), thyrotropin (TSH) levels were within the normal range and not determined to be hypothyroid. There was no proteinuria in the spot urine test, nephrotic syndrome was not considered. Pleural fluid acid-resistant bacilli (ARB) and mycobacterial culture was negative. Pathology of the pleural fluid detected hypocellular, proteinaceous fluid and foamy histiocytes. Chylothorax was regressed with conservative treatment. One month later, chest $\mathrm{x}$-ray control radiograph showed bilateral pleural thickening (Figure 4).

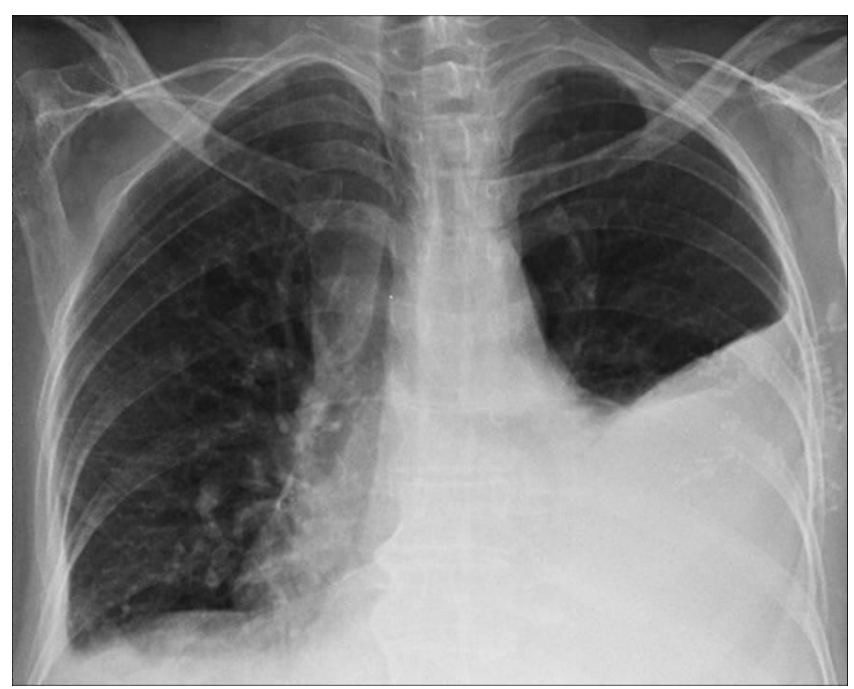

Figure 1: Chest $x$-ray showed left homogenoeus density with a concave interface toward the lung and blunting of the right costophrenic angle

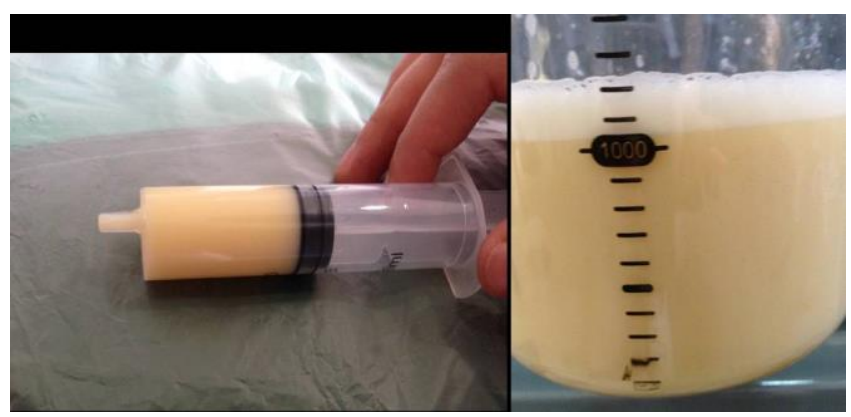

Figure 2: Milky off-white pleural fluid

\section{DISCUSSION}

Thoracic duct transports chyle and lymph from the intestines, liver, abdominal wall and lower extremities into the systemic venous system. The thoracic duct transports digestive fat into the venous system. Chyle is derived from 
the intestinal lacteal system, which gives it a characteristic milky appearance. Chyle contains significant quantities of chylomicron, triglyceride and, cholesterol. The other constituent, namely lymph, including lymphocytes, immunoglobulins. Chylothorax is the leakage of chyle into the pleural space. Trauma of the thoracic duct and malignant disease (non-Hodgkin's lymphoma) are the common mechanisms of chylothorax (4). Other rare causes are lymphangiomyomatosis, tuberculosis, venous thrombosis, congenital lymphatic malformations, nephrotic syndrome, hypothyroidism, cirrhosis and idiopathic chylothorax. The incidence of chylothorax following esophagectomy varies between $0.5 \%$ and $3.8 \%(5-6)$. In one study, idiopathic chylothorax made up $9 \%$ of chylothoraces (4).

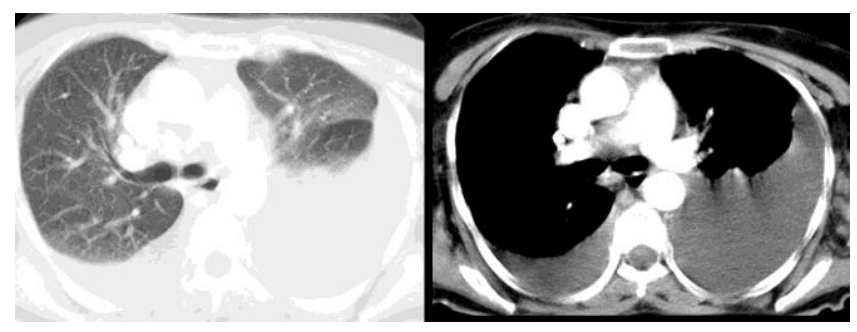

Figure 3: Chest computed tomogram showed bilateral pleural effusion more prominent on the left

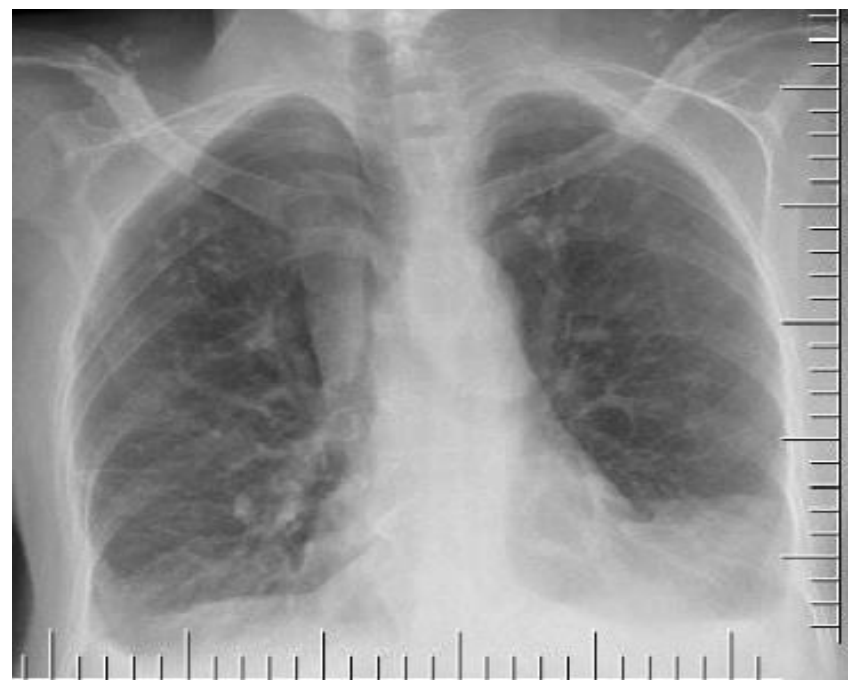

Figure 4: One month later. Chest radiograph showed bilateral pleural thickening

A diagnosis of chylothorax is made by ruling out other causes (7). In this case, the thyroid function tests of patient were normal and there was no proteinuria in the patient's spot urine test. Pleural fluid acid-fast bacilli examination was negative and biochemical analysis hepatic tests were normal. Ascites was not found with abdominal ultrasound. Nephrotic syndrome, tuberculosis, cirrhosis and hypothyroidism were not detected.
Although the etiology is unknown, the majority of spontaneous chylothorax cases are associated with minor traumas, such as coughing, vomiting, and stretching. In this case, a temporal relationship with physical exercise, as well as the absence of a specific cause, led to the diagnosis of spontaneous chylothorax.

Chylothorax symptoms are nonspecific and are related to the presence of liquid in the thoracic cavity, dyspnea, and fatigue. The biochemical criterion for chylothorax is when the pleural fluid triglyceride level is greater than 110 $\mathrm{mg} / \mathrm{dL}$. Pleural fluid with a triglyceride level greater than $110 \mathrm{mg} / \mathrm{dL}$ has less than a $1 \%$ chance of not being chylous (8). Conversely, a pleural fluid triglyceride level less than $50 \mathrm{mg} / \mathrm{dL}$ indicates no more than a $5 \%$ chance of being chylous. The detection of chylomicron using lipoprotein analysis is considered to be the "gold standard" investigation, but it is not routinely available in many medical centers (9). It is helpful, however, in borderline cases when the triglyceride level is between 110 and 50 $\mathrm{mg} / \mathrm{dL}$ (10). Treatment for chylothorax depends on the etiology. Radiotherapy and chemotherapy can be used in the control of chylothorax, secondary to lymphoma and metastasis. In cases of spontaneous chylothorax, the treatment consists of preventing dehydration, nutrition maintenance and a reduction in the chyle formation rate (1). In small lesions, the duct frequently regenerates spontaneously, and no surgical procedure is necessary. With extensive lesions, invasive treatment with pleurodesis or a pleuroperitoneal shunt is indicated. Our patient's diagnosis of chylothorax was confirmed, but the etiology was not determined.

We presented a case of idiopathic-bilateral chylothorax, which is more unusual than other chylothorax. Another important issue is that our patient did not require any surgery procedures. We treated our patient conservatively, with intercostal tube drainage and total parenteral nutrition.

\section{CONFLICTS OF INTEREST}

None declared.

\section{AUTHOR CONTRIBUTIONS}

Concept - I.G.Ç., B.M.; Planning and Design - I.G.Ç., B.M.; Supervision - I.G.Ç., B.M.; Funding - I.G.Ç.; Materials - I.G.Ç.; Data Collection and/or Processing - I.G.Ç.; Analysis and/or Interpretation - I.G.Ç.; Literature Review I.G.Ç.; Writing - I.G.Ç.; Critical Review - I.G.Ç. 


\section{YAZAR KATKILARI}

Fikir - I.G.Ç., B.M.; Tasarım ve Dizayn - I.G.Ç., B.M.; Denetleme - I.G.Ç., B.M.; Kaynaklar - I.G.Ç.; Malzemeler - I.G.Ç.; Veri Toplama ve/veya İşleme - I.G.Ç.; Analiz ve/veya Yorum - I.G.Ç.; Literatür Taraması - I.G.Ç.; Yazıyı Yazan - I.G.Ç.; Eleştirel İnceleme - I.G.Ç.

\section{REFERENCES}

1. Kamiyoshihara M, Ibe T, Kakegawa S, Sato K, Takise A, Takeyoshi I. Late-onset chylothorax after blunt chest trauma at an interval of 20 years: report of a case. Surg Today 2008; 38:56-8. [CrossRef]

2. Demirhan R, Cevik A, Kucuk HF, Altintas M, Kurt N. Travmatik şilotoraks: Olgu sunumu. Turkish J Thorac Cardiovasc Surg 2003; 11:50-1.

3. Nair SK, Petko M, Hayward MP. Aetiology and management of chylothorax in adults. Eur J Cardiothorac Surg 2007; 32:362-9. [CrossRef]
4. Turan O, Ozsan H, Dicle O, Akkoclu A. A case of chylothorax due to primary renal lymphoma. Case Reports in Internal Medicine 2014; 1:183-6. [CrossRef]

5. Shah RD, Luketich JD, Schuchert MJ, Christie NA, Pennathur A, Landreneau RJ, et al. Postesophagectomy chylothorax: incidence, risk factors, and outcomes. Ann Thorac Surg 2012; 93:897-903. [CrossRef]

6. Cobanoglu U, Sayır F, lliklerden DM, Bartın K. Şilotoraks tedavisinde cerrahiye alternatif bir metot: Somatostatin uygulanması. Van Tıp Dergisi 2010; 17(2):54-7.

7. Torrejais JC, Rau CB, de Barros JA, Torrejais MM. Spontaneous chylothorax associated with light physical activity. J Bras Pneumol 2006; 32:599-602.

8. Maldonado F, Hawkins FJ, Daniels CE, Doerr CH, Decker PA, Ryu JH. Pleural fluid characteristics of chylothorax. Mayo Clin Proc 2009; 84:129-33. [CrossRef]

9. Senkaya I, Yılmaz M, Guven H, Ozer ZG, Ozkan H. Kunt toraks travması sonrası şilotoraks. Turkish J Thorac Cardiovasc Surg. 1995; 3:194-6.

10. McGrath EE, Barber C. Bilateral pleural effusions. CMAJ 2010; 182:1879-82. [CrossRef] 